\title{
Studies on Tikka Disease: Effect of Sowing Dates on the Biochemical Parameters of Groundnut
}

\author{
S.K. Mushrif ${ }^{1,2}$, M.J. Manju ${ }^{1}$, T.H. Shankarappa ${ }^{1}$ and Nagaraju ${ }^{2}$ \\ ${ }^{1}$ Departments of Plant Pathology and Agricultural Microbiology, University of Horticultural \\ Sciences, Bagalkot- 587 104, India \\ ${ }^{2}$ Department of Plant Pathology, University of Agricultural Sciences, Bengaluru- 560 065, India \\ *Corresponding author
}

\section{A B S T R A C T}

\section{Keywords}

Tikka disease, Sowing season, Varieties, Total sugars, Total phenols, Total proteins.

Article Info

Accepted:

18 February 2017

Available Online:

10 March 2017
A field experiment was conducted at Boodamanahalli village, (Bangalore rural district) to know the effect of tikka disease, caused together by Cercospora arachidicola and Cercosporidium personatum on biochemical parameters viz., total sugars, total phenols and total proteins as influenced by different sowing dates in groundnut. It included two varieties, TMV-2 a highly susceptible one and GBPD-4 a resistant with nine sowing dates starting from December 2008 to August 2009 at monthly intervals. The results revealed that total sugars, total phenols and total proteins did not vary much irrespective of different sowing dates, variety and season in the initial stages of the crop as the disease was very low. On the contrary, there was decrease in the total sugar and increase in the total phenols and total proteins contents with the increase in disease severity of the crop age. These changes were more pronounced in TMV-2 variety during kharif season than summer season and all these changes were comparatively less pronounced in GPBD-4 variety revealing that these factors had possible influence on biochemical parameters.

\section{Introduction}

Groundnut is one of the major oilseed crops grown in India accounting for approximately $32 \%$ of oil seed area and $39 \%$ of oil seed production (Ghenvande and Nanda Gopal, 1997). In Karnataka, it is grown in an area of 8.18 lakh hectares, production of 4.57 lakh tones and yield of $589 \mathrm{Kg}$ per hectare (Anon, 2011). Its productivity is quite low in India compared to that of USA, China and other countries. Many factors are contributing to the low yield and one among them is the disease. Groundnut crop suffers from many important diseases among which rust (Puccinia arachidis), early leaf spot (Cercospora arachidicola) and late leaf spot (Cercosporidium personatum) are more prevalent and destructive in nature. The latter two diseases together are referred to as tikka disease of groundnut. Tikka and rust diseases can cause yield losses up to 70\% (McDonald et al., 1985; Miller et al., 1990; Grichar et al., 1998) resulting in a lower productivity of the crop. Avoidable losses up to $45 \%$ due to tikka, up to $42 \%$ due to rust and up to $60 \%$ due to both have been reported in Karnataka (Siddaramaiah et al., 1983). In addition to losses in pod yield, this disease also affects quality of haulm which is a nutritious fodder 
(Alabi et al., 1993). The existing fungicidal control measures are neither economical nor environmental friendly; therefore an economic and eco-friendly way to manage the disease effectively is required. Identification of resistant varieties and alteration of sowing time can be a better agronomic practice to control the diseases; in this regard we attempted two verities and different sowing dates to evaluate the severity of tikka disease and its effects on nutritional quality of groundnut.

\section{Materials and Methods}

A field experiment was conducted at Boodamanahalli village, (Bangalore Rural district) to know the effect of tikka disease severity on the biochemical parameters viz., total sugars, total phenols and total proteins in groundnut as influenced by different sowing dates. The experiment had nine sowing dates starting from December 2008 to August 2009 involving two varieties TMV-2, a highly susceptible variety and GBPD-4, a resistant variety. The experiment was laid out in Randomized Block Design (RBD) with three replications having a gross plot size of $3 \mathrm{M} \mathrm{X}$ $3 \mathrm{M}$ and a net plot size of $2.8 \mathrm{M} \mathrm{X} 2.8 \mathrm{M}$ with a spacing of $30 \times 10 \mathrm{~cm}$. The trial was carried out without the protected sprays. The disease severity was recorded at 3 different stages of the crop growth 30, 60, and 90 DAS. Five plants were selected in each replication for the disease assessment. The severity of the disease was recorded as disease score as per the modified scale given by Subbarao et al., (1990). The per cent disease intensity (PDI) was computed as per the formula suggested by Horsefall and Heuberger (1942).

$\mathrm{PDI}=$

Sum of numerical rating X 100

No. of leaves examined $\times$ max. sevearity grade
The biochemical parameters viz., total sugars, total phenols and total proteins estimations, leaf samples were collected at 30,60 and 90 DAS from 5 plants selected at random from each replication and were brought to the laboratory in ice cube box. Desired quantity for each parameter was weighed and the samples were dipped in liquid nitrogen to arrest the metabolic activities and later stored in $-70^{\circ} \mathrm{C}$ deep freezer for further use. The total sugar and total phenol contents were estimated by Anthrone Reagent and FolinCiocalteau reagent methods respectively (Sadasivam and Manickam, 1996), the total protein was estimated using the method suggested by Lowry et al., (1951) and all the data pertaining to disease severity and biochemical parameters were analyzed statistically.

\section{Results and Discussion}

\section{Effect of disease severity on total sugars}

The sowing dates had no significant effect on disease severity and total sugar content in the variety TMV-2 at 30 DAS (Table 1). There was increase in disease severity and it had decreased the total sugar content at 60 DAS. Maximum disease severity (23.33 PDI) was registered for August month sown crop resulting in minimum total sugar content (36.74 $\mathrm{mg} \mathrm{g}^{-1}$ of fresh leaf) which was followed by July sown crop with disease severity of 13.50 per cent and total sugar content of $40.70 \mathrm{mg} \mathrm{g}^{-1}$ of fresh leaf. At 90 DAS, the total sugar content decreased further rapidly with increase in disease severity and it was more pronounced in kharif crops than in summer crops. The minimum total sugar content of $29.75 \mathrm{mg} \mathrm{g}^{-1}$ of fresh leaf was recorded from August sown crop which had the highest disease severity (71.07 per cent) followed by July (31.94 $\mathrm{mg} \mathrm{g}^{-1}$ of fresh leaf) which recorded the disease severity of 63.90 per cent. The low total sugar content and high 
disease severity during August and July months sown crop is perhaps due to onset of winter season at pod inducing period that would result into translocation of nutrients in to pods as well as chilling temperature and humidity that encourage the crop damage by pathogens (Vara Prasad et al., 1999).

Variety, GPBD-4 did not show variation in total sugar content at 30 DAS but at 60 DAS, the total sugar content had decreased with increase in disease severity (Table 2). The sharp decrease in the total sugar contents during severe disease conditions in the susceptible variety TMV-2 may be due to rapid hydrolysis of sugars during pathogenesis through the enzymes secreted by the pathogen (Jayapal and Mahadevan, 1968; Kaur and Dhillon, 1989). However, the increase in disease severity was less in GPBD-4 compared to TMV-2 variety and also there was less reduction in the total sugar content. Susceptible cultivars showed a rapid decrease of sugars but the decrease was relatively slow in resistant cultivars (Sindhan et al., 1999; Suryawanshi et al., 2006). The maximum disease severity (6.70 PDI) was registered in August month sown crop followed by July month sown crop (2.20 PDI) resulting in minimum total sugar content for August (40.70 $\mathrm{mg} \mathrm{g}^{-1}$ of fresh leaf) and July (43.89 $\mathrm{mg} \mathrm{g}^{-1}$ of fresh leaf) sown crops respectively. There was further increase in disease severity at 90 DAS and corresponding decrease in the total sugar content. The maximum total sugar content was observed in January month sown crop (42.37 $\mathrm{mg} \mathrm{g}^{-1}$ of fresh leaf) with a lowest disease severity of 5.27 per cent and the July and August months sown crops (34.12 and $35.24 \mathrm{mg} \mathrm{g}^{-1}$ of fresh leaf) had showed minimum total sugar content and disease severity (15.40 and 19.00 per cent) respectively and were on par with each other. The higher total sugar content and low disease severity during January and February months sown crop is perhaps due to onset of summer season at pod inducing period and good sunny days resulting in better photosynthesis and accumulation of sugars and presence of high temperature and low humidity that would discourage the fungal pathogens (Sergeeva et al., 2009).

\section{Effect of disease severity on total phenols}

The data from table (Table 3) indicates that the different sowing dates had no significant effect on the total phenol content and disease severity in TMV-2 variety at 30 DAS. Minimum total phenol content $\left(36.13 \mathrm{mg} \mathrm{g}^{-1}\right.$ of fresh leaf) was noticed in February sown crop which also recorded the minimum disease severity of 7.73 per cent, however, a maximum total phenol content $\left(47.52 \mathrm{mg} \mathrm{g}^{-1}\right.$ of fresh leaf) and a maximum disease severity 23.33 per cent was observed in July and August months sown crops respectively at 60 DAS. The disease was severity was found to be very high at 90 DAS with highest total phenol content and it was more pronounced in kharif season than in summer season. The maximum total phenol content of $73.58 \mathrm{mg} \mathrm{g}$ ${ }^{1}$ of fresh leaf was recorded for August month sown crop which had the highest disease severity (71.07 per cent) followed by was July month sown crop.

The total phenol content in GPBD-4 (Table 4) at 30 DAS did not differ much. At 60 DAS, increase in total phenol content was observed with increase in disease severity. However, the increase in disease severity was less compared to TMV-2 variety. The increase in the total phenolic contents in the susceptible variety TMV-2 during high disease severity may be due to the enhancements in the synthesis, translocation of phenolics to the site of infection and hydrolysis of phenolic glycosides by fungal glycosidase to yield free phenols. Brahmachari and Kolte, 1983; Sindhan et al.,1999; Jyosthna et al., 2004 noticed higher 
levels of total phenol content at all growth stages of groundnut plant resistant to late leaf spot than susceptible cultivars. A maximum total phenol content $\left(54.29 \mathrm{mg} \mathrm{g}^{-1}\right.$ of fresh leaf) and maximum disease severity 6.70 per cent was observed in August month sown crop. At 90 DAS, disease severity had increased further with a corresponding increase in the total phenol content; the August month sown crop had showed maximum total phenol content $\left(76.18 \mathrm{mg} \mathrm{g}^{-1}\right.$ of fresh leaf) and maximum disease severity of 19.00 per cent. It was followed by July month sown crop, which registered the total phenol content (70.12 $\mathrm{mg} \mathrm{g}^{-1}$ of fresh leaf) and disease severity (15.40 per cent). The total phenol contents had increased as a mechanism of defense by the plant, with disease severity and the disease onset is correlated for prevailing congenial temperature and humidity demanded by the pathogens (Narayana Reddy and Khare, 1988).

\section{Effect of disease severity on total proteins}

The total protein content as influenced by sowing dates in variety, TMV-2 at 30 DAS (Table 5) showed less disease severity. At 60 DAS, the total protein content was found to be directly correlated with disease severity. There was increase in total protein content (24.67 $\mathrm{mg} \mathrm{g}^{-1}$ of fresh leaf) in April month sown crop which showed a disease severity of 5.07 per cent. At 90 DAS, the total protein content as well as disease severity had increased and it was more pronounced in kharif crop than in summer crop. Maximum total protein content $\left(36.25 \mathrm{mg} \mathrm{g}^{-1}\right.$ of fresh leaf) was recorded from August month sown crop with disease severity of 71.07, followed by was July month sown crop while the minimum total protein content $\left(26.86 \mathrm{mg} \mathrm{g}^{-1}\right.$ of fresh leaf) was recorded in April month sown crop which had disease severity of 35.37 per cent.

Table.1 Effect of tikka disease severity on total sugar content in groundnut var. TMV-2 as influenced by different sowing dates

\begin{tabular}{|c|c|c|c|c|c|c|}
\hline \multirow[b]{3}{*}{$\begin{array}{c}\text { Sowing } \\
\text { Dates }\end{array}$} & \multicolumn{6}{|c|}{ Total sugar content ( $\mathrm{mg} \mathrm{g}^{-1}$ of fresh leaf) } \\
\hline & \multicolumn{2}{|c|}{30 DAS } & \multicolumn{2}{|c|}{60 DAS } & \multicolumn{2}{|c|}{90 DAS } \\
\hline & $\begin{array}{c}\text { Disease } \\
\text { Severity }(\%)\end{array}$ & $\begin{array}{c}\text { Total } \\
\text { sugars }\end{array}$ & $\begin{array}{c}\text { Disease } \\
\text { Severity }(\%)\end{array}$ & $\begin{array}{c}\text { Total } \\
\text { sugars }\end{array}$ & $\begin{array}{c}\text { Disease } \\
\text { Severity }(\%)\end{array}$ & $\begin{array}{r}\text { Total } \\
\text { sugars }\end{array}$ \\
\hline Dec. & $0.20(4.80)$ & 58.55 & $10.17(19.06)$ & 46.59 & $33.20(35.49)$ & 40.39 \\
\hline Jan. & $0.13(4.56)$ & 59.89 & $06.77(15.64)$ & 50.45 & $34.40(36.21)$ & 45.63 \\
\hline Feb. & $0.17(4.68)$ & 60.85 & $07.73(16.67)$ & 51.26 & $35.07(36.61)$ & 46.25 \\
\hline Mar. & $0.10(4.44)$ & 62.27 & $01.63(8.40)$ & 55.08 & $18.57(25.89)$ & 48.23 \\
\hline Apr. & $0.23(4.91)$ & 60.01 & $05.07(13.65)$ & 50.23 & $35.37(36.79)$ & 45.35 \\
\hline May & $0.77(6.46)$ & 57.74 & $07.13(16.04)$ & 49.20 & $53.30(47.18)$ & 36.48 \\
\hline Jun. & $0.37(5.34)$ & 56.69 & $09.53(18.47)$ & 46.19 & $58.77(50.34)$ & 38.07 \\
\hline Jul. & $0.80(6.55)$ & 56.01 & $13.50(21.97)$ & 40.70 & $63.90(53.37)$ & 31.94 \\
\hline Aug. & $0.37(5.34)$ & 57.21 & $23.33(29.22)$ & 36.74 & $71.07(57.78)$ & 29.75 \\
\hline SEm \pm & 0.30 & 0.43 & 0.19 & 0.48 & 0.37 & 0.47 \\
\hline $\begin{array}{l}\text { CD @ } \\
5 \%\end{array}$ & 0.89 & 1.34 & 0.57 & 1.43 & 1.11 & 1.40 \\
\hline
\end{tabular}

Note: Figures in parenthesis are arcsine transformed values DAS - Days after sowing 
Table.2 Effect of tikka disease severity on total sugar content in groundnut var. GPBD-4 as influenced by different sowing dates

\begin{tabular}{|c|c|c|c|c|c|c|}
\hline \multirow{3}{*}{$\begin{array}{l}\text { Sowing } \\
\text { Dates }\end{array}$} & \multicolumn{6}{|c|}{ Total sugar content ( $\mathrm{mg} \mathrm{g}^{-1}$ of fresh leaf) } \\
\hline & \multicolumn{2}{|c|}{30 DAS } & \multicolumn{2}{|c|}{$60 \mathrm{DAS}$} & \multicolumn{2}{|c|}{90 DAS } \\
\hline & $\begin{array}{c}\text { Disease } \\
\text { Severity }(\%)\end{array}$ & $\begin{array}{c}\text { Total } \\
\text { sugars }\end{array}$ & $\begin{array}{c}\text { Disease } \\
\text { Severity }(\%)\end{array}$ & $\begin{array}{c}\text { Total } \\
\text { sugars }\end{array}$ & $\begin{array}{c}\text { Disease } \\
\text { Severity }(\%)\end{array}$ & $\begin{array}{l}\text { Total } \\
\text { sugars }\end{array}$ \\
\hline Dec. & $0.00(4.05)$ & 52.37 & $02.23(9.52)$ & 47.24 & $05.20 \quad(13.81)$ & 41.29 \\
\hline Jan. & $0.00(4.05)$ & 52.46 & $01.60(8.33)$ & 47.54 & $05.27 \quad(13.89)$ & 42.37 \\
\hline Feb. & $0.00(4.05)$ & 52.06 & $01.60(8.33)$ & 46.17 & $(15.38)$ & 41.26 \\
\hline Mar. & $0.00(4.05)$ & 52.85 & $01.53(8.20)$ & 47.86 & (11.59) & 41.89 \\
\hline Apr. & $0.00(4.05)$ & 53.06 & $02.00(9.10)$ & 46.83 & (13.89) & 40.26 \\
\hline May & $0.57(5.93)$ & 51.40 & $01.57(8.27)$ & 45.72 & (18.84) & 38.06 \\
\hline Jun. & $0.33(5.24)$ & 51.51 & $02.40(9.80)$ & 46.16 & $(22.16)$ & 39.01 \\
\hline Jul. & $0.57(5.93)$ & 49.06 & $02.20(9.46)$ & 43.89 & $(23.50)$ & 34.12 \\
\hline Aug. & $0.00(4.05)$ & 48.85 & $06.70(15.56)$ & 40.70 & $19.00 \quad(26.21)$ & 35.24 \\
\hline SEm \pm & 0.15 & 0.44 & 0.24 & 0.47 & 0.27 & 0.42 \\
\hline $\begin{array}{l}\text { CD @ } \\
\mathbf{5 \%}\end{array}$ & 0.45 & 1.32 & 0.72 & 1.42 & 0.80 & 1.26 \\
\hline
\end{tabular}

Note: Figures in parenthesis are arcsine transformed values

DAS - Days after sowing

Table.3 Effect of tikka disease severity on total phenol content in groundnut var. TMV-2 as influenced by different sowing dates

\begin{tabular}{lcccccc}
\hline & \multicolumn{6}{c}{ Total phenol content $\left(\mathbf{m g ~ g}^{-1}\right.$ of fresh leaf) } \\
\cline { 2 - 7 } $\begin{array}{l}\text { Sowing } \\
\text { Dates }\end{array}$ & $\begin{array}{c}\text { 30 DAS } \\
\text { Disease } \\
\text { Severity } \\
(\boldsymbol{\%})\end{array}$ & $\begin{array}{c}\text { Total } \\
\text { phenols }\end{array}$ & $\begin{array}{c}\text { 60 DAS } \\
\text { Disease } \\
\text { Severity (\%) }\end{array}$ & $\begin{array}{c}\text { Total } \\
\text { phenols }\end{array}$ & $\begin{array}{c}\text { 90 DAS } \\
\text { Deverity (\%) }\end{array}$ & $\begin{array}{c}\text { Total } \\
\text { phenols }\end{array}$ \\
\hline Dec. & $0.20(4.80)$ & 31.87 & $10.17(19.06)$ & 41.24 & $33.20(35.49)$ & 54.27 \\
Jan. & $0.13(4.56)$ & 30.28 & $06.77(15.64)$ & 37.17 & $34.40(36.21)$ & 56.46 \\
Feb. & $0.17(4.68)$ & 26.49 & $07.73(16.67)$ & 36.13 & $35.07(36.61)$ & 56.24 \\
Mar. & $0.10(4.44)$ & 27.07 & $01.63(8.40)$ & 38.17 & $18.57(25.89)$ & 54.29 \\
Apr. & $0.23(4.91)$ & 29.88 & $05.07(13.65)$ & 40.27 & $35.37(36.79)$ & 56.17 \\
May & $0.77(6.46$ & 28.65 & $07.13(16.04)$ & 46.23 & $53.30(47.18)$ & 61.28 \\
Jun. & $0.37(5.34)$ & 30.89 & $09.53(18.47)$ & 45.17 & $58.77(50.34)$ & 67.14 \\
Jul. & $0.80(6.55)$ & 33.01 & $13.50(21.97)$ & 47.52 & $63.90(53.37)$ & 68.23 \\
Aug. & $0.37(5.34)$ & 31.28 & $23.33(29.22)$ & 47.48 & $71.07(57.78)$ & 73.58 \\
\hline SEm \pm & $\mathbf{0 . 3 0}$ & $\mathbf{0 . 6 0}$ & $\mathbf{0 . 1 9}$ & $\mathbf{0 . 7 7}$ & $\mathbf{0 . 3 7}$ & $\mathbf{0 . 7 3}$ \\
CD @ 5\% & $\mathbf{0 . 8 9}$ & $\mathbf{1 . 7 9}$ & $\mathbf{0 . 5 7}$ & $\mathbf{2 . 3 0}$ & $\mathbf{1 . 1 1}$ & $\mathbf{2 . 2 0}$ \\
\hline
\end{tabular}

Note: Figures in parenthesis are arcsine transformed values DAS - Days after sowing 
Table.4 Effect of tikka disease severity on total phenol content in groundnut var. GPBD-4 as influenced by different sowing dates

\begin{tabular}{lcccccc}
\hline \multirow{2}{*}{$\begin{array}{l}\text { Sowing } \\
\text { Dates }\end{array}$} & \multicolumn{2}{c}{ 30 DAS } & \multicolumn{3}{c}{ Total phenol content $\left(\mathbf{m g ~ g}^{-1}\right.$ of fresh leaf) } \\
\cline { 2 - 7 } & $\begin{array}{c}\text { Disease } \\
\text { Severity (\%) }\end{array}$ & $\begin{array}{c}\text { Total } \\
\text { phenols }\end{array}$ & $\begin{array}{c}\text { Disease } \\
\text { Severity (\%) }\end{array}$ & $\begin{array}{c}\text { Total } \\
\text { phenols }\end{array}$ & $\begin{array}{c}\text { Disease } \\
\text { Severity (\%) }\end{array}$ & $\begin{array}{c}\text { Total } \\
\text { phenols }\end{array}$ \\
\hline Dec. & $0.00(4.05)$ & 35.27 & $02.23(9.52)$ & 48.17 & $05.20(13.81)$ & 61.27 \\
Jan. & $0.00(4.05)$ & 33.62 & $01.60(8.33)$ & 44.25 & $05.27(13.89)$ & 62.23 \\
Feb. & $0.00(4.05)$ & 30.84 & $01.60(8.33)$ & 41.85 & $06.53(15.38)$ & 60.92 \\
Mar. & $0.00(4.05)$ & 33.24 & $01.53(8.20)$ & 43.24 & $03.53(11.59)$ & 63.28 \\
Apr. & $0.00(4.05)$ & 31.45 & $02.00(9.10)$ & 44.19 & $05.27(13.89)$ & 63.49 \\
May & $0.57(5.93)$ & 33.28 & $01.57(8.27)$ & 54.27 & $09.93(18.84)$ & 66.28 \\
Jun. & $0.33(5.24)$ & 35.87 & $02.40(9.80)$ & 53.44 & $13.73(22.16)$ & 67.23 \\
Jul. & $0.57(5.93)$ & 33.47 & $02.20(9.46)$ & 52.17 & $15.40(23.50)$ & 70.12 \\
Aug. & $0.00(4.05)$ & 35.08 & $06.70(15.56)$ & 54.29 & $19.00(26.21)$ & 76.18 \\
\hline SEm \pm & $\mathbf{0 . 1 5}$ & 0.75 & $\mathbf{0 . 2 4}$ & 0.62 & $\mathbf{0 . 2 7}$ & 0.66 \\
CD @ & $\mathbf{0 . 4 5}$ & 2.26 & $\mathbf{0 . 7 2}$ & 1.84 & $\mathbf{0 . 8 0}$ & 1.97 \\
$\mathbf{5 \%}$ & & & & &
\end{tabular}

Note: Figures in parenthesis are arcsine transformed values DAS - Days after sowing

Table.5 Effect of tikka disease severity on total protein content in groundnut var. TMV-2 as influenced by different sowing dates

\begin{tabular}{|c|c|c|c|c|c|c|}
\hline \multirow{3}{*}{$\begin{array}{c}\text { Sowing } \\
\text { Dates }\end{array}$} & \multicolumn{6}{|c|}{ Total protein content $\left(\mathrm{mg} \mathrm{g}^{-1}\right.$ of fresh leaf) } \\
\hline & \multicolumn{2}{|c|}{30 DAS } & \multicolumn{2}{|c|}{ 60 DAS } & \multicolumn{2}{|c|}{90 DAS } \\
\hline & $\begin{array}{c}\text { Disease } \\
\text { Severity } \\
(\%)\end{array}$ & $\begin{array}{c}\text { Total } \\
\text { proteins }\end{array}$ & $\begin{array}{c}\text { Disease } \\
\text { Severity }(\%)\end{array}$ & $\begin{array}{c}\text { Total } \\
\text { proteins }\end{array}$ & $\begin{array}{c}\text { Disease } \\
\text { Severity }(\%)\end{array}$ & $\begin{array}{c}\text { Total } \\
\text { proteins }\end{array}$ \\
\hline Dec. & $0.20(4.80)$ & 19.74 & $10.17(19.06)$ & 22.42 & $33.20(35.49)$ & 27.55 \\
\hline Jan. & $0.13(4.56)$ & 21.32 & $06.77(15.64)$ & 23.89 & $34.40(36.21)$ & 29.34 \\
\hline Feb. & $0.17(4.68)$ & 20.89 & $07.73(16.67)$ & 24.01 & $35.07(36.61)$ & 27.23 \\
\hline Mar. & $0.10(4.44)$ & 22.94 & $01.63(8.40)$ & 24.29 & $18.57(25.89)$ & 28.67 \\
\hline Apr. & $0.23(4.91)$ & 21.85 & $05.07(13.65)$ & 24.67 & $35.37(36.79)$ & 26.86 \\
\hline May & $0.77(6.46$ & 19.43 & $07.13(16.04)$ & 23.64 & $53.30(47.18)$ & 30.16 \\
\hline Jun. & $0.37(5.34)$ & 19.27 & 09.53 (18.47) & 25.64 & $58.77(50.34)$ & 32.80 \\
\hline Jul. & $0.80(6.55)$ & 17.69 & $13.50(21.97)$ & 21.25 & $63.90(53.37)$ & 33.42 \\
\hline Aug. & $0.37(5.34)$ & 17.24 & $23.33(29.22)$ & 23.14 & $71.07(57.78)$ & 36.25 \\
\hline SEm \pm & 0.30 & 0.61 & 0.19 & 0.49 & 0.37 & 0.80 \\
\hline CD@ $0 \%$ & 0.89 & 1.82 & 0.57 & 1.48 & 1.11 & 2.40 \\
\hline
\end{tabular}

Note: Figures in parenthesis are arcsine transformed values

DAS - Days after sowing 
Table.6 Effect of tikka disease severity on total protein content in groundnut var. GPBD-4 as influenced by different sowing dates

\begin{tabular}{|c|c|c|c|c|c|c|}
\hline \multirow{3}{*}{$\begin{array}{c}\text { Sowing } \\
\text { Dates }\end{array}$} & \multicolumn{6}{|c|}{ Total protein content ( $\mathrm{mg} \mathrm{g}^{-1}$ of fresh leaf) } \\
\hline & \multicolumn{2}{|c|}{30 DAS } & \multicolumn{2}{|c|}{ 60 DAS } & \multicolumn{2}{|c|}{90 DAS } \\
\hline & $\begin{array}{c}\text { Disease } \\
\text { Severity } \\
(\%)\end{array}$ & $\begin{array}{c}\text { Total } \\
\text { proteins }\end{array}$ & $\begin{array}{c}\text { Disease } \\
\text { Severity } \\
(\%)\end{array}$ & $\begin{array}{c}\text { Total } \\
\text { proteins }\end{array}$ & $\begin{array}{c}\text { Disease } \\
\text { Severity }(\%)\end{array}$ & $\begin{array}{c}\text { Total } \\
\text { proteins }\end{array}$ \\
\hline Dec. & $0.00(4.05)$ & 22.64 & $02.23(9.52)$ & 26.32 & $05.20(13.81)$ & 28.13 \\
\hline Jan. & $0.00(4.05)$ & 23.19 & $01.60(8.33)$ & 24.86 & $05.27(13.89)$ & 28.34 \\
\hline Feb. & $0.00(4.05)$ & 24.12 & $01.60(8.33)$ & 25.04 & $06.53(15.38)$ & 27.49 \\
\hline Mar. & $0.00(4.05)$ & 24.87 & $01.53(8.20)$ & 28.21 & $03.53(11.59)$ & 31.28 \\
\hline Apr. & $0.00(4.05)$ & 24.19 & $02.00(9.10)$ & 26.89 & $05.27(13.89)$ & 28.84 \\
\hline May & $0.57(5.93)$ & 22.15 & $01.57(8.27)$ & 27.49 & 09.93 (18.84) & 29.86 \\
\hline Jun. & $0.33(5.24)$ & 22.86 & $02.40(9.80)$ & 26.45 & $13.73(22.16)$ & 32.43 \\
\hline Jul. & $0.57(5.93)$ & 20.19 & $02.20(9.46)$ & 24.15 & $15.40(23.50)$ & 32.16 \\
\hline Aug. & $0.00(4.05)$ & 20.14 & $6.70(15.56)$ & 25.63 & $19.00(26.21)$ & 31.15 \\
\hline SEm \pm & 0.15 & 0.58 & 0.24 & 0.63 & 0.27 & 0.74 \\
\hline CD@ $9 \%$ & 0.45 & 1.75 & 0.72 & 1.89 & 0.80 & 2.20 \\
\hline
\end{tabular}

Note: Figures in parenthesis are arcsine transformed values

DAS - Days after sowing

The total protein content in variety, GPBD-4 did not show much variation due to sowing months at 30 DAS (Table 6) and it had maximum protein content of $24.87 \mathrm{mg} \mathrm{g}^{-1}$ of fresh leaf for the crop sown during the month of March also which showed zero per cent disease severity. At 60 DAS, total protein content showed increasing trend as there was increase in disease severity. The increase in disease severity was less in GPBD-4 compared to TMV-2 variety, this increase in the total protein content in susceptible variety TMV-2 may be due to the super imposing effect of pathogen protein on host protein level (Kaur and Dhillon, 1989; Rani and Reddy, 1998). Here also, maximum total protein content $\left(28.21 \mathrm{mg} \mathrm{g}^{-1}\right.$ of fresh leaf) was noticed in March month sown crop with lowest disease severity of 1.53 and a minimum total protein content was observed in July month sown crop $\left(24.15 \mathrm{mg} \mathrm{g}^{-1}\right.$ of fresh leaf) which recorded the disease severity of 2.20. At $90 \mathrm{DAS}$, there was further increase in the total protein content and a corresponding increase in disease severity.
The highest total protein content $\left(32.43 \mathrm{mg} \mathrm{g}^{-}\right.$ ${ }^{1}$ of fresh leaf) was observed in June month sown crop followed by July month sown crop (32.16 $\mathrm{mg} \mathrm{g} \mathrm{g}^{-1}$ of fresh leaf) along with respective disease severity of 13.73 and 15.40 per cent where as the lowest total protein content was recorded in February month sown crop (27.49 $\mathrm{mg} \mathrm{g}^{-1}$ of fresh leaf) with disease severity of 6.53 per cent.

The increase in the total protein content in susceptible variety TMV-2 may be due to the super imposing effect of pathogen protein on host protein level (Rani and Reddy, 1998). The variation in total protein contents due to different sowing time suggests that the plant translocates higher concentration of protein to pod setting when there is less disease severity as the plant need not have to compete with pathogen effect and hence the February month sown crop with high temperature and low humidity during maturity and pod bearing stage accumulated less protein in the leaves (Narayana Reddy and Khare, 1988). 
From the results it was concluded that in the initial stages of the crop there was not much variation in total sugars, total phenols and total proteins as the disease was very low. However, the disease severity started increasing as a result of crop aging; there was reduction in total sugars whereas an increasing trend was noticed for total phenols and total proteins. The changes particularly in total sugars and total proteins were much more pronounced in the susceptible variety TMV-2 sown in kharif season than in summer season sown crop indicating the possible influence of disease severity on biochemical parameters. On the other hand, these changes in above said two parameters were comparatively less pronounced in the resistant variety GPBD-4. However, the increase in total phenols was more in the resistant variety GPBD-4 than in TMV-2.

\section{References}

Alabi, O., Olorunju, P.E., Misari, S.M. and Boye-Goni, S.R. 1993. Management of groundnut foliar diseases in Samaru, Northern Nigeria, In: Summary proceedings of the Third regional Groundnut meeting for West Africa, 1417 Sep., 1992, Ouagadougou, Burkina Faso.

Anonymous. 2011. Fully revised estimates of principal crops in Karnataka for the year 2009-10, Directorate of Economics and Statistics, Bangalore, pp176.

Brahmachari, B.K. and Kolte, S.J. 1983. Morphological and biochemical difference in two Cercospora leaf spot resistant and susceptible varieties of groundnut, Indian Phytopath., 36: 149150.

Ghenvande, M.P. and Nanda Gopal, V. 1997. Integrated pest management in groundnut in India 1997, Integrated. Pest Management Rev., 2: 1-15.

Grichar, W.J., Besler, B.A. and Jaks, A.J.
1998. Peanut (Arachis hypogaea L.) cultivar response to leaf spot disease development under four disease management programs, Peanut Sci., 25: 35-39.

Horsefall, J.G. and Heuberger, J.W. 1942. Measuring the magnitude of a defoliation disease of tomato, Phytopath., 32: 226-232.

Jayapal, R. and Mahadevan, A. 1968. Biochemical changes in banana leaves in response to leaf spot pathogenesis. Indian Phytopath., 21: 43-48.

Jyosthna, M.K., Reddy, N.P.E. Chalam, T.V. and Reddy, G.L.K. 2004. Morphological and biochemical characterization of Phaeoisariopsis personata resistant and susceptible cultivars of groundnut (Arachis hypogaea), Pl. Pathol. Bull., 13: 243-250.

Kaur, J. and Dhillon, M. 1951. Biochemical alterations in groundnut (Arachis hypogaea L.) leaf induced by Cercosporidium personatum (Berk and Curt.) Deighton, Indian J. Mycol. Pl. Pathol., 19: 151-156.

Lowry, O.H., Rosebrough, N.J., Farr, A.C. and Randall, P.J. 1951. Protein measurement with the folin- phenol reagent, J. Biol. Chem., 193: 265-277.

Mcdonald, D.P., Subrahmanyan, Gibbon, R.W. and Smith, D.H. 1985. Early and late leaf spots of groundnut, Information Bulletin No. 21, ICRISAT, Patancheru, Andhra Pradesh, India, pp 24.

Miller, I.L., Norden, A.J., Knauft, D.A. and Gorbet, D.W. 1990. Influence of maturity and fruit yield on susceptibility of peanut to Cercosporidium personatum (late leaf spot pathogen). Peanut Sci., 17: 52-58.

Narayana Reddy, P. and Khare, M.N. 1988. Physiology of groundnut rust disease changes in total sugars phenols, ascorbic acid, peroxidase and phenol 
oxidase. J. Oil seeds Res., 5: 102-106.

Rani, A.S. and Reddy, G.M. 1998. Biochemical differences in compatible and incompatible interactions of groundnut leaf spot induced by Cercospora arachidicola, Legume Res., 21: 188-192.

Sadasivam, S. and Manickam, A. 1996. Biochemical methods, New Age International (P) Limited Publishers, New Delhi, pp. 256.

Sergeeva, V., Spooner-Hart, R. and Nair, N. 2008. First report of Colletotrichum acutatum and C. gloeosporioides causing leaf spots of olives (Olea europaea) in Australia. Australasian Plant Dis. Notes, 3: 143-144.

Siddaramaiah, A.L., Desai, S.A. and Hegde, R.K. 1983. Studies on estimation of loss due to rust and tikka of groundnut, Mysore J. Agric. Sci., 17: 365-367.

Sindhan, G.S., Jaglan, B.S. and Parashar, R.D. 1987. Changes in phenols and carbohydrates in resistant and susceptible cultivars of groundnut in relation to tikka disease, Plant Dis. Res., 2: 100-101.

Subbarao, P.V., Subrahmanyam, P. and Reddy, P.M. 2006. A modified 9 point scale for assessment of rust and late leaf spot of groundnut. In: $2^{\text {nd }}$ International congress of the French Phytopathol. Society, 28-30 Nov., 1990, Montpellier, France.

Suryawanshi, A.P., Mayee, C.D., Dhoke, P.K. and Indulkar, B.S. 2006. Role of phenols and sugars in resistance of groundnut against late leaf spot caused by Phaeoisariopsis personata. J. Pl. Dis. Sci., 1: 195-197.

Vara Prasad, P.V., P.Q. Craufurd, and R.J. Summerfield. 1999. Sensitivity of peanut to timing of heat stress during reproductive development. Crop Sci., 39: 1352-1357.

\section{How to cite this article:}

Mushrif, S.K., M.J. Manju, T.H. Shankarappa and Nagaraju. 2017. Studies on Tikka Disease: Effect of Sowing Dates on the Biochemical Parameters of Groundnut. Int.J.Curr.Microbiol.App.Sci. 6(3): 1010-1018. doi: https://doi.org/10.20546/ijcmas.2017.603.119 